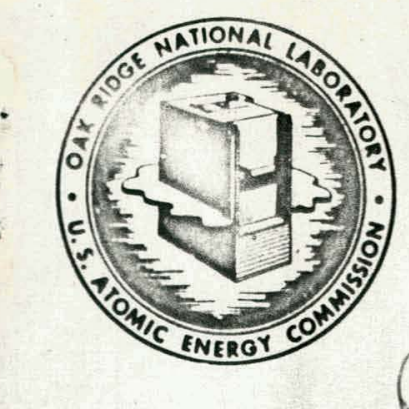

DATE:

\section{OAK RIDGE NATIONAL LABORATOKY \\ Operated by UNION CARBIDE NUCLEAR COMPANY \\ Division of Union Corbide Corporation}

UCC

Post Office Box X

Oak Ridge, Tennessee

subJect: CEC's PMC - 144 D Oil Diffusion Pump(Nominal 6" Prototype).

TO:

FROM:

C.E. Normand

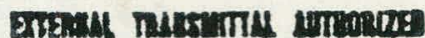

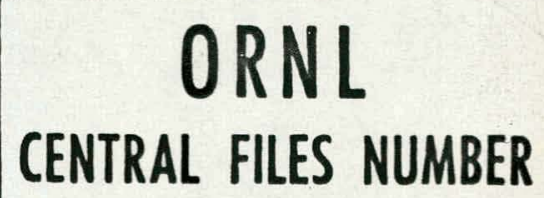

$59-6-80$

COPYNO. 路

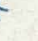




\section{DISCLAIMER}

This report was prepared as an account of work sponsored by an agency of the United States Government. Neither the United States Government nor any agency Thereof, nor any of their employees, makes any warranty, express or implied, or assumes any legal liability or responsibility for the accuracy, completeness, or usefulness of any information, apparatus, product, or process disclosed, or represents that its use would not infringe privately owned rights. Reference herein to any specific commercial product, process, or service by trade name, trademark, manufacturer, or otherwise does not necessarily constitute or imply its endorsement, recommendation, or favoring by the United States Government or any agency thereof. The views and opinions of authors expressed herein do not necessarily state or reflect those of the United States Government or any agency thereof. 


\section{DISCLAIMER}

Portions of this document may be illegible in electronic image products. Images are produced from the best available original document. 


\title{
CEC'S PMC - 144 D OIL DIFFUSION PUMP
}

(NOMINAL 6" PROTOTYPE)

\author{
C. E. Normand
}

Thlo pump was made avallable to us for testing over a period of about a week. The results of our tests are summarized in this report.

1. Structural Features. This is designated as a 6" pump because It is built on a standard 6" pipe flange. The actual barrel diameter 1s 7-I/4": The barrel length is $18^{\prime \prime}$; and overall space required is $11 " \times 15-1 / 2 " \times 21^{n}$. Both Intake and discharge flanges are designed to use aluminum wire gaskets.

The cooling coll is of $1 / 4^{\prime \prime}$ copper tubing, taper wound from I" apacing at the top to $3 / 4$ " at the bottom. The cooling coll extends down only to the level of the lowest jet.

The jet assembly is of a completely new "stub" aesign providing (4) stages of diffusion pumping.

The heating arrangement is novel. It consists of $s 1 x$ (6) $3 / 8^{\prime \prime}$ $x 5^{\prime \prime}$ finger type heaters, rated at 300 watts each. Each heater slips into a blind tube extending upward about $3^{\prime \prime}$ through the boller base plate. Each heater tube has six (6) $9 / 16^{\prime \prime}$ radial fins extending along its whole length. The whole tube-fin assembly is surrounded by a close fitting metal sleeve 1-I/2"....D. by $3 "$ high, slotted for oil flow beneath 1ts lower rim.

2. Operating Conditions. Stnadard operating conditions, as previously determined by C.E.C. In their tests, were maintained throughout our tests except as these. were arbitrarily varled as part of the test. These conditions were: (a) Power - 1800 watts. (b) Coollng water flow $1 \mathrm{c} / \mathrm{min}$. or to maintain discharge temperature at $35-40^{\circ} \mathrm{C}$. (c) Pump fluid - Convoll-20.

\section{Performance.}

(a). Speed: The unbaffled pumping speed for a1r was measured over the $10^{-4}$ to $2 \times 10^{-6}$ mm pressure range, and was found to decrease from about $1040^{\mathrm{i}} \mathrm{i} / \mathrm{sec}$. to $860 \mathrm{I} / \mathrm{sec} .(\overline{\mathrm{s}}=950 \mathrm{I} / \mathrm{sec}$. $)$. Th1s is significantly less than the speed found by C.E.C. 
- about $1300 \mathrm{c} / \mathrm{sec}$ from $2 \times 10^{-3}$ to $3 \times 10^{-5} \mathrm{~mm}$ (See speed curves, Fig. 1).

In comparing these speeds it should be noted that different pump fluids and slightly different operating powers were used in the two tests. Also, our pressures were measured with a VG-IA Ionization gage: C.E.C.'s measurements were based on pressures measured with a trapped McLeod gage. This difference in gages accounts for the different pressure ranges covered, and may have contributed to the differences in speed. The most important difference in the two sets of speed measurements 1s probably that of test domes. C.E.C.'s test dome had the diameter of the barrel, and a helght of about $1-1 / 2$ diameters. Our measurements were from a dome 20 in. In diameter and $20 \mathrm{in.} \mathrm{high.} \mathrm{It} \mathrm{appears} \mathrm{that} \mathrm{speeds} \mathrm{measure} \mathrm{with}$ these two arrangements should differ by the effective pump aperture conductance effect. This, indeed, proves to be the case.

The relative merits of Ionization and McLeod gages for speed measurements, nor of large vs. small test domes need not be settled here. For comparing the speed performance of this pump with other pumps familiar to us, we consider the ion gage based speeds as more valid because the accepted speeds of existing pumps have been determined by this method. Also we prefer the large test dome as giving a more direct measure of what the pump will do in a practical installation.

Even on this basis the speed of the PMC-144D pump per unit area of pump aperture is a gratifying high $23 \mathrm{~L} / \mathrm{sec} / \mathrm{In}^{-2}$.

(b) IImiting Fore Pressure: The limiting static fore pressure, 1.e. at zero input, is a remarkable $400 \mu$. Even more remarkable, this fore pressure limit is not appreclably depressed at the largest applied through puts-up to $1 / 2$ atmosphere c.c.

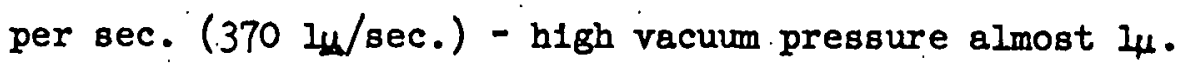

(c) Pressure Stab1l1ty: Large pressure fluctuations were never observed. A low amplitude, high frequency fluctuation that appeared clearly on the recorder chart only when recording from the $10^{-7}$ mange of the gage, proved to be due to leaks at the aluminum gasket. 


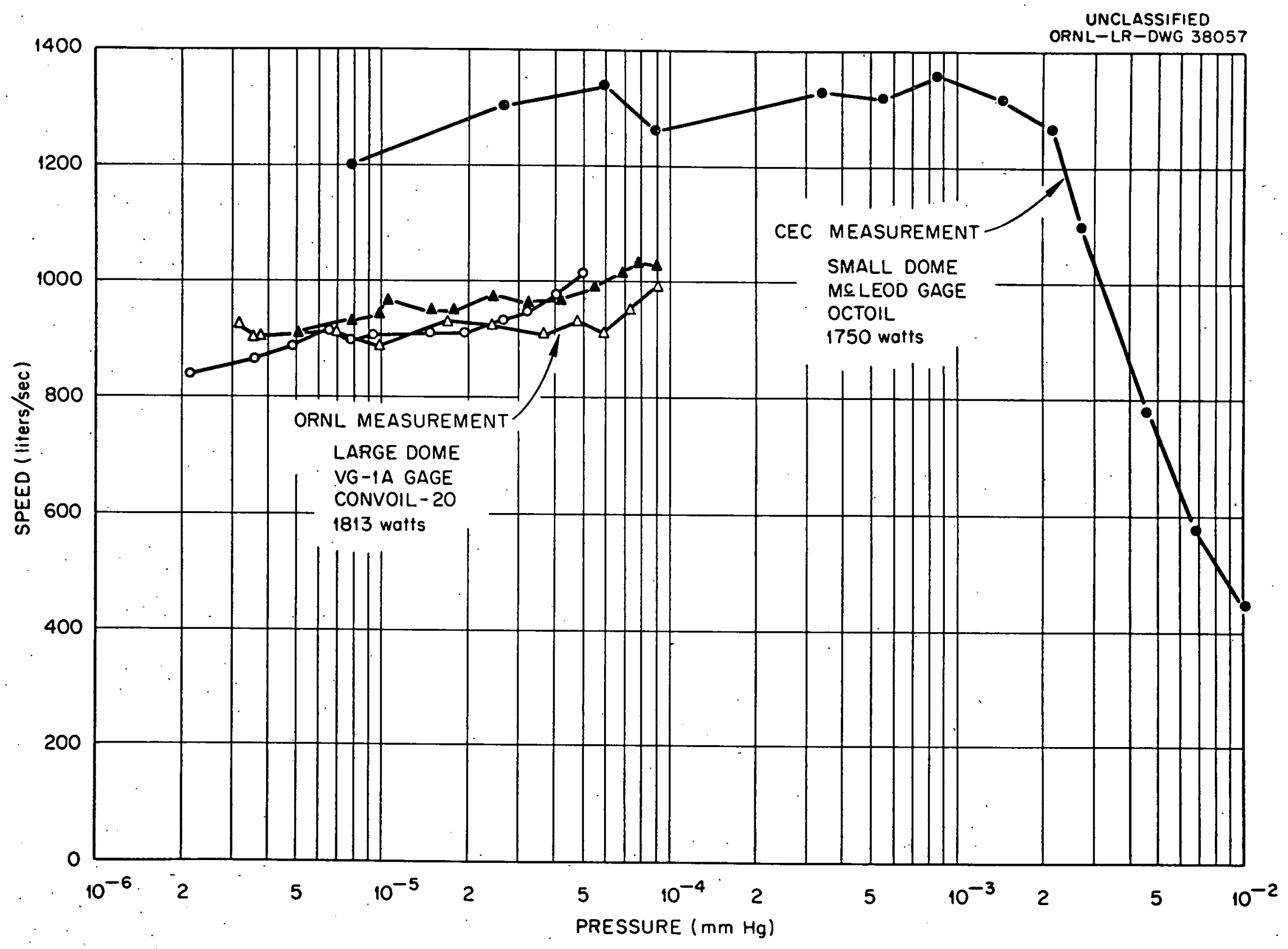

Fig. 1. Unbaffled Pumping Speed for Air. CEC's PMC $-144 D$ 


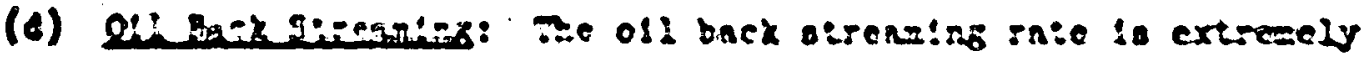

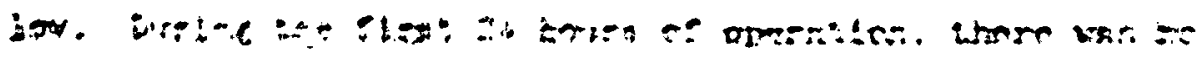
detectable collection. During the next 48 hours, a total collection (In two burettes) of 1.25 cc was made - apparently at a constant rate. This indicates a back streaming rate of $.026 \mathrm{cc} / \mathrm{hr}$. Continued running for an additional 70 hours gave $.0434 \mathrm{cc} / \mathrm{hr}$. as the back streaming rate.

(e) Ult1mate Pressure: No particular effort was made to determine the true ultimate pressure of which the pump (unbaffled) is capable. The pressure quoted is merely the lowest stable pressure observed in the system to which this pump was connected. The low pressure obtalned was $5 \times 10^{-7} \mathrm{~m}$. 'This 1s less than the lowest pressure obtained in the same system with a 10 in., MCF-1400, modified to reduce back streaming.

(f) Effect of Power Varlation: The input power to the pump was varied in 6 stages from a maximum of. 2150 watts to a minimum of 1060 watts. The only noticeable effect was a reduction of limiting fore pressure from about $450 \mu$ to $225 \mu$. Base pressure and pressure fluctuations were essentlally unchanged.

(8) Effect of Water-flow Variation: Adjusting cooling water flow to outlet temperature of $21^{\circ} \mathrm{C}:-39^{\circ} \mathrm{C}:-61^{\circ} \mathrm{C}$ produced no clearly detectable changes in performance. Ultimate pressure may be slightly higher at both extremes - but this is not definite. Limiting fore pressure is probably slightly lower at the highest rate of flow $(375 \mu$ vB $400 \mu)$.

4. Probable Causes of Improved Performance: It is quite impossible in a short test to evaluate Individually such changes as new jet shapes, shorter vapor stacks, etc. There are, however, three novel features of this pump which probably contribute substantially to 1ts performance.

(a) The heater arrangement permits the application of higher power per unit area without causing "bumping" and "splashing". Thus the boller runs at higher pressure than the conventional pumps, due both to higher density and higher temperature. Jets are, therefore, both "strong" and "dry". These conditions lead to low back streaming and low ultimste pressure. 
(b) The 4th pumping stage, employing a very short, high pressure jet, accounts for the high limiting fore pressure.

(c) The stopping of cooling colls even with the fourth stage, together with large power Input, cause the lower pump barrel to run unusually hot. Thus considerable fractionation and dealration of returning oll occurs outside the boller. This also contributes to low ultimate pressure.

5. Evaluation: As compared with conventional o1l diffusion pumps; e.8. C.E.C.'s MCF series, this pump is superior in every major respect, except in power consumption. It

(a) Requires less space;

(b) Gives higher pumping speed per unit area,

(c) Operates at higher fore pressure

(d) Obtains lower ultimate pressure,

(e) Is less subject to pressure fluctuations. Also it is relatively insensitive to variations in power, cooling, etc.

I consider it a distinct advance in oll diffusion pump design.

6. Avallability: According to Mr. Stevenson, CEC is planning to produce a complete Iine of pumps of this type - 2 in. to 32 in. nominal size. Prototypes of the 2 in, 4 in, and 6 in. pumps have been bullt. The 6 in. pump will be first put 1nto production. Expected release data, f1rst quarter 1959. The $10 \mathrm{in.} \mathrm{w11l.probably} \mathrm{be}$ avallable during the second quarter. The larger sizes $20 \mathrm{ln}$, and 32 in. are still in experimental design. 